Supporting Information

\title{
Binding of Amino Acids into a Novel Multiresponsive Ferrocene Receptor having Ene-Backbone
}

Paromita Debroy, ${ }^{a}$ Moloy Banerjee, ${ }^{a}$ Madhumita Prasad, ${ }^{b}$ Satya P. Moulik, ${ }^{b}$ and Sujit Roy ${ }^{\mathrm{a}, *}$

\section{${ }^{a}$ Organometallics \& Catalysis Laboratory, Chemistry Department}

Indian Institute of Technology, Kharagpur 721302, India

sroy@chem.iitkgp.ernet.in

${ }^{\mathrm{b}}$ Centre for Surface Science, Department of Chemistry

Jadavpur University, Kolkata 700032, India

CONTENTS

PAGE No.

\section{Experimental:}

General Methods \& procedures for the synthesis of $\mathbf{1}$, and $\mathbf{2}$

General Procedures - UV-vis, Fluorescence, CV, NMR, ITC, ESI-MS studies

Figures S1a - S1 j:

(Benesi-Hildebrand plots):

Absorption Titration, Emission Titration, ${ }^{13} \mathrm{C}$ NMR Titration

Figures S2a - S2d:

${ }^{13} \mathrm{C}$ NMR of receptor $\mathbf{1}$, before and after the addition of Glu

Figures S3a - S31:

ES+ and ES- spectra from ESI-MS studies of $\mathbf{1}$ and $\mathbf{2}$ with guests

Figures S4a - 4f:

$\mathrm{CV}$ of Receptor $\mathbf{1}$ after adding excess of Guest

Figure S5:

Plot showing linear correlation of $K_{\mathrm{ox}} / K_{\text {red }}$ ratio with $\Delta E_{1 / 2}$ value

Table S1:

Electrochemical data of $\mathbf{1}$ in the presence of amino acid guests 
General Method: All reactions were performed under an inert atmosphere of argon. All the starting materials were $>98 \%$ pure vide NMR. Anhydrous solvents were dried by usual procedures and stored over molecular sieves. Silica gel (60-120 mesh SRL) was used for column chromatography. Dibenzyltinoxide, dibenzyltindiisothiocyanate and 1,1'bisformylferrocene were prepared according to literature procedures [ (a) Majumdar, K. K.; Kundu, A.; Das, I.; Roy, S. Appl. Organomet. Chem. 2000, 14, 79. (b) Wada, M.; Nishino, M.; Okawara, R. J. Organomet. Chem. 1965, 3, 70. (c) Balavoine, G. G. A.; Doisneau, G.; Khan, T. F. J. Organomet. Chem. 1991, 412, 381].

${ }^{1} \mathrm{H}(200 \mathrm{MHz})$ and ${ }^{13} \mathrm{C}$ NMR $(54.6 \mathrm{MHz})$ was recorded on Brucker-AC $200 \mathrm{MHz}$ spectrometer at $300 \mathrm{~K}$. IR spectra were obtained using a Perkin-Elmer 883 spectrophotometer. EIMS (70 eV) spectra were recorded using Autospec-M mass spectrometer. ESI-MS spectra were taken on Waters LCT mass spectrometer. UV-visible spectra were recorded at 293 K on Shimadzu UV-1601 UV-Vis Spectrometer. The electrochemical data were acquired with a Model 600A Electrochemical Analyzer $\mathrm{CH}$ Instruments with a conventional three-electrode configuration consisting of platinum working and auxiliary electrodes and $\mathrm{Ag} / \mathrm{AgCl}$ reference electrode, and tetra-n-butylammonium perchlorate $(0.1 \mathrm{M})$ as the supporting electrolyte. Elemental analyses were performed on Perkin Elmer Instruments 2400 Series II CHNS/O Analyzer. Fluorescence spectra were taken on Spex Flurolog 3 (Model No.FL3-11). Isothermal Titration Calorimetry studies were conducted on a VP-ITC Microcalorimeter from Microcal, Inc. (Northampton, MA). For binding studies, chromatographically homogeneous reference standard grade L-amino acids (SRL), HPLC grade solvents, and Milli-Q water was used.

\section{Ferrocenyl-1, 1'-bis(ethyl acrylate)}

Fc-1, $1^{\prime}-\left[\mathrm{CH}_{\mathrm{a}}=\mathrm{CH}_{\mathrm{b}}-\mathrm{C}(=\mathrm{O}) \mathrm{O}-\mathrm{CH}_{2 \mathrm{c}} \mathrm{CH}_{3 \mathrm{~d}}\right]_{2}$ (2).

A mixture of 1,1'-bisformylferrocene $(4.36 \mathrm{~g}, 18 \mathrm{mmol})$ and ethoxycarbonylmethylene-triphenylphosphorane $(17.5 \mathrm{~g}$, $50 \mathrm{mmol}$ ) was refluxed in dry benzene $(50 \mathrm{~mL})$ for $4 \mathrm{~h}$. Following solvent removal, the residue was triturated with dichloromethane. The organic extract was washed with water and brine, and dried over anhydrous magnesium sulfate. After removal of solvent, the mixture was subjected to column chromatography over silica gel (gradient elution using ethylacetate-hexane) to afford 2 as red crystalline solid (5.1 g, 75\%). $\mathrm{R}_{\mathrm{f}}=0.26$ (hexane/ethylacetate 9:1v/v). ${ }^{1} \mathrm{H}-\mathrm{NMR}$ $\left(200 \mathrm{MHz}, \mathrm{CDCl}_{3}\right): \delta=4.36\left(\mathrm{~m}, 4 \mathrm{H}, \mathrm{C}_{5} \mathrm{H}_{4}\right) ; 4.45\left(\mathrm{~m}, 4 \mathrm{H}, \mathrm{C}_{5} \mathrm{H}_{4}\right) ; 5.94\left(\mathrm{~d}, 2 \mathrm{H}, \mathrm{J}=16 \mathrm{~Hz}, \mathrm{H}_{\mathrm{a}}\right) ; 7.37\left(\mathrm{~d}, 2 \mathrm{H}, \mathrm{J}=16 \mathrm{~Hz}, \mathrm{H}_{\mathrm{b}}\right)$; 4.20 (q, 4H, J=7 Hz, $\left.\mathrm{H}_{\mathrm{c}}\right) ; 1.37$ (t, 6H, J=7 Hz, $\left.\mathrm{H}_{\mathrm{d}}\right) .{ }^{13} \mathrm{C}-\mathrm{NMR}\left(\mathrm{CDCl}_{3}, \delta \mathrm{ppm}\right): 69.8,72.3\left(\mathrm{Cp}_{\text {unsubst }}\right) ; 80.0\left(\mathrm{Cp}_{\text {subst }}\right) ; 143.8$ $(\mathrm{Fc}-\mathrm{C}=) ; 116.3(=\mathrm{C}-) ; 166.9(\mathrm{C}=\mathrm{O}) ; 60.2\left(\mathrm{CH}_{2}\right) ; 14.3\left(\mathrm{CH}_{3}\right)$. EI-MS: $\mathrm{m} / \mathrm{z}$ (relative intensity): $382\left(\mathrm{M}^{+}, 100\right) ; 383(\mathrm{M}+1$, 21); 219 (59); 191 (14); 175 (47); 145 (21); 121 (23); 89 (21); 56 (11). IR (KBr, cm ${ }^{-1}$ ): 500m, 950m, 1045m, 1170vs, 1200vs, 1300m, 1630s, 1720vs ( $\gamma_{\mathrm{C}=\mathrm{O}} \mathrm{str}$ ), 2950w. HRMS Calcd For $\mathrm{C}_{20} \mathrm{H}_{22} \mathrm{O}_{4}$ Fe. m/z 382.0867 Found m/z 382.2178. Anal. Found: C, 61.91; H, 5.98. Calcd. For $\mathrm{C}_{20} \mathrm{H}_{22} \mathrm{O}_{4} \mathrm{Fe}$ : C, 62.15; H, 5.80\%.

\section{Ferrocenyl-1,1'-bis[(1-hydroxy-2-butenyl)acrylate]}

Fc-1, $1^{\prime}-\left[\mathrm{CH}_{\mathrm{a}}=\mathrm{CH}_{\mathrm{b}}-\mathrm{C}(=\mathrm{O}) \mathrm{O}-\mathrm{CH}_{2 \mathrm{c}} \mathrm{CH}_{\mathrm{d}}=\mathrm{CH}_{\mathrm{e}} \mathrm{CH}_{2 \mathrm{f}} \mathrm{OH}_{\mathrm{g}}\right]_{2}$ (1).

To a solution of 2 (955 mg, $2.5 \mathrm{mmol}$ ) and 1-hydroxy,3-(isothiocyanato)tetrabenzyldistannoxane (17 mg, $10 \mathrm{~mol} \%)$ in dioxane $(15 \mathrm{~mL})$ was added cis-but-2-ene-1,4-diol $(20 \mathrm{ml})$. The solution was refluxed at bath temperature $130^{\circ} \mathrm{C}$. After completion of the reaction (TLC monitoring, silica gel, ethylacetate-hexane; 2:3 v/v), the solvent was evaporated under reduced pressure. The resulting red oil was triturated with dichloromethane $(10 \times 25 \mathrm{~mL})$, washed with water, finally dried over anhydrous sodium sulfate. Following solvent removal, the mixture was subjected to column chromatography over silica gel (gradient elution using ethylacetate-hexane) to afford 1 as red solid (775 $\mathrm{mg}, 66 \%$ ) which was stored under minimum exposure to light. $\mathrm{mp} 66-67^{\circ} \mathrm{C}$. TLC (Silica gel/ethylacetate-hexane 2:3 v/v) $\mathrm{R}_{\mathrm{f}}=0.06 .{ }^{1} \mathrm{H}$ NMR $(200$ $\left.\mathrm{MHz}, \mathrm{CD}_{3} \mathrm{CN}\right) \delta=4.57\left(\mathrm{t}, 4 \mathrm{H}, \mathrm{J}=1.7 \mathrm{~Hz}, \mathrm{C}_{5} \mathrm{H}_{4}\right), 4.41\left(\mathrm{t}, 4 \mathrm{H}, \mathrm{J}=1.7 \mathrm{~Hz}, \mathrm{C}_{5} \mathrm{H}_{4}\right), 5.94\left(\mathrm{~d}, 2 \mathrm{H}, \mathrm{J}=16 \mathrm{~Hz}, \mathrm{H}_{\mathrm{a}}\right), 7.27(\mathrm{~d}, 2 \mathrm{H}$, $\left.\mathrm{J}=16 \mathrm{~Hz}, \mathrm{H}_{\mathrm{b}}\right), 4.69\left(\mathrm{~d}, 4 \mathrm{H}, \mathrm{J}=6 \mathrm{~Hz}, \mathrm{H}_{\mathrm{c}}\right), 5.62\left(\mathrm{~m}, 2 \mathrm{H}, \mathrm{H}_{\mathrm{d}}\right), 5.75\left(\mathrm{~m}, 2 \mathrm{H}, \mathrm{H}_{\mathrm{e}}\right), 4.15\left(\mathrm{dd}, 4 \mathrm{H}, \mathrm{J}=6 \mathrm{~Hz}, \mathrm{~J}=6 \mathrm{~Hz}, \mathrm{H}_{\mathrm{f}}\right), 2.98(\mathrm{t}$, $2 \mathrm{H}, \mathrm{J}=6 \mathrm{~Hz}, \mathrm{OH}) ;{ }^{13} \mathrm{C}-\mathrm{NMR}\left(\mathrm{CD}_{3} \mathrm{CN}, \delta\right) 73.2,70.9\left(\mathrm{Cp}_{\text {unsubst }}\right) ; 81.0\left(\mathrm{Cp}_{\text {subst }}\right) ; 145.2$ (alkenyl); 116.5 (alkenyl); 60.9 (O- 
$\left.\mathrm{CH}_{2}\right) ; 126.0$ (alkenyl); 134.7 (alkenyl); $58.6\left(\mathrm{CH}_{2} \mathrm{OH}\right) ; 167.4(\mathrm{C}=\mathrm{O}) ;$ EI-MS: m/z (relative intensity) $466\left(\mathrm{M}^{+}, 100\right)$; 378 (31); 261 (8); 191 (58); 173 (9); 146 (15); 118 (19); 91 (15); 56 (7); IR (KBr, cm ${ }^{-1}$ ) 1030m, 1120w, 1360w, 1405w, 1600m, 1700m, 2900m, 3400vs; UV/Vis (MeCN, $\lambda_{\max }$, nm (log $\left.\varepsilon\right)$ ) 479 (3.0), 306 (4.2), 257 (4.4), 208 (4.3); HRMS calcd for $\mathrm{C}_{24} \mathrm{H}_{26} \mathrm{O}_{6} \mathrm{Fe} . \mathrm{m} / \mathrm{z} 489.0976[\mathrm{M}+\mathrm{Na}]^{+}$, found $\mathrm{m} / \mathrm{z}$ 489.0968. Anal. Calcd. for $\mathrm{C}_{24} \mathrm{H}_{26} \mathrm{O}_{6} \mathrm{Fe}: \mathrm{C}, 61.82 ; \mathrm{H}, 5.62$. Found: C, 61.39; H, 5.70.

1-Hydroxy,3-(isothiocyanato)tetrabenzyldistannoxane: A mixture of dibenzyltinoxide (416 mg, 1 mmol), dibenzyltindiisothiocyanate $(945 \mathrm{mg}, 3 \mathrm{mmol})$ and dehydrated ethanol $(10 \mathrm{ml})$ was refluxed for $12 \mathrm{~h}$ till a clear solution is reached. The yellow solid obtained after concentration was extracted with acetone. Slow addition of methanol to the acetone solution yielded the title compound as a pale white solid (150 mg, 22\%). Anal $\left(\mathrm{C}_{29} \mathrm{H}_{29} \mathrm{NO}_{2} \mathrm{SSn}\right)$ calcd: $\mathrm{C}$ : 50.26, H: 4.22; found: C 49.80, H: 4.59 .

General Procedure for UV-visible Titration: To a solution of $1\left(1 \times 10^{-5} \mathrm{M}, 2.5 \mathrm{~mL}\right.$ in $\left.\mathrm{MeCN}^{-} \mathrm{H}_{2} \mathrm{O} 55: 45 \mathrm{v} / \mathrm{v}\right)$ was added small aliquots of the stock solution of the examined guests $\left(4.9 \times 10^{-4} \mathrm{M}\right.$ in $\mathrm{MeCN}-\mathrm{H}_{2} \mathrm{O} 55: 45 \mathrm{v} / \mathrm{v}$ at $\left.\mathrm{pH} 7.2\right)$. The absorbance readings were taken after each addition and were adjusted to take into account the dilution of the solution during the course of each addition. The relative absorbance change was recorded as a function of guest concentrations.

General Procedure for Cyclic Voltammetric Measurements: The examined guests $\left(1 \times 10^{-2} \mathrm{M}\right.$ in $\mathrm{MeCN}_{-} \mathrm{H}_{2} \mathrm{O} 55: 45$ $\mathrm{v} / \mathrm{v}$ at $\mathrm{pH} 7.2)$ were added as aliquots to a solution of receptor $1\left(1 \times 10^{-3} \mathrm{M}\right.$ in $\left.\mathrm{MeCN}-\mathrm{H}_{2} \mathrm{O} 55: 45 \mathrm{v} / \mathrm{v}\right)$. Anaerobic conditions were maintained by the use of an argon atmosphere. A scan rate of $50 \mathrm{mV} \mathrm{s}^{-1}$ was employed with a sweep from 0.4 to +1.0 to 0.4 . The redox potential $\left(E_{1 / 2}\right)$ of 1 was measured with respect to $\mathrm{Ag} / \mathrm{Ag}^{+}$. The data were calibrated using $\mathrm{Fc} / \mathrm{Fc}^{+}$couple $\left(\mathrm{E}_{1 / 2}=0.46\right)$.

Typical Procedure for Fluorescence Titration Studies with 1 and Glu: To a solution of $1\left(1 \times 10^{-4} \mathrm{M}, 2.5 \mathrm{~mL}\right.$ in $\left.\mathrm{MeCN}-\mathrm{H}_{2} \mathrm{O} 55: 45 \mathrm{v} / \mathrm{v}\right)$ was added small aliquots of the stock solution of Glu $\left(4.9 \times 10^{-3} \mathrm{M}\right.$ in $\mathrm{MeCN}^{-\mathrm{H}_{2} \mathrm{O}} 55: 45 \mathrm{v} / \mathrm{v}$ at $\mathrm{pH}$ 7.2). The fluorescence intensity readings after each addition were adjusted to take into account the dilution of the solution during the course of each addition. The relative fluorescence change was recorded as a function of glutamic acid concentrations.

Typical Procedure for Isothermal Titration Calorimetry Studies: To a solution of 1 (1.325 mL, $1 \mathrm{mM}$ in MeCN$\mathrm{H}_{2} \mathrm{O} 55: 45 \mathrm{v} / \mathrm{v}$ ) was added L-glutamic acid (41.6 mM in $\mathrm{MeCN}_{-} \mathrm{H}_{2} \mathrm{O} 55: 45 \mathrm{v} / \mathrm{v}$ at $\mathrm{pH}$ 7.2) by the designated portions (4 $\mu \mathrm{L}$ each) at $303 \mathrm{~K}$ with continuous stirring $(250 \mathrm{rpm})$ and the heat of complexation was recorded. Control experiments were done to measure the heat released due to the mixing of receptor/solvent or glutamic acid/solvent per injections. The corrected heat of complexation data was used to obtain the binding isotherm, which was further fitted with one binding site model using MICROCAL ORIGIN 2.9 software. Hence the enthalpy change ( $\Delta H$ in Kcal/mol), association constant $\left(K\right.$ in $\left.\mathrm{M}^{-1}\right)$, and binding ratio $(n)$ were obtained

ESI-MS Studies: ESI-MS spectra were taken on Micromass LCT mass spectrometer working in the electrospray ionization in mass range $100-1100 \mathrm{~m} / \mathrm{z}$. The sample cone and extraction cone voltage were appropriately varied to prevent in-source dissociation. Appropriate calibration was done before each experiment. The spectra were acquired for solutions in 1:1 $\mathrm{MeCN}-\mathrm{H}_{2} \mathrm{O}$ (HPLC grade). For the interaction study a solution containing equimolar concentration of guest and receptor (1 or $\mathbf{2})$ were used.

${ }^{13}$ C NMR Titration Studies: To a solution of receptor $1\left(1.6 \times 10^{-1} \mathrm{M}, 0.4 \mathrm{~mL}\right)$ in $\mathrm{CD}_{3} \mathrm{CN}$ was added a solution of Glu $\left(3.2 \times 10^{-1} \mathrm{M}, \mathrm{pH} 7.6\right.$ in $\mathrm{D}_{2} \mathrm{O}$ adjusted by $\left.\mathrm{NaOD}\right)$ in $50 \mu \mathrm{L}$ portions to a total of $250 \mu \mathrm{L}$. Further addition of guest produced no change in the chemical shift of the carbons. Control studies indicated that in the absence of guest, the chemical shifts of the carbons were not concentration dependent. The ${ }^{13} \mathrm{C}$ chemical shift changes were monitored as a function of molar equivalents of glutamic acid. 


\section{(Benesi-Hildebrand plots):}

Absorption Titration (Fig S1a - S1g), Emission Titration (Fig S1h), ${ }^{13}$ C NMR Titration (Fig S1i - S1j)

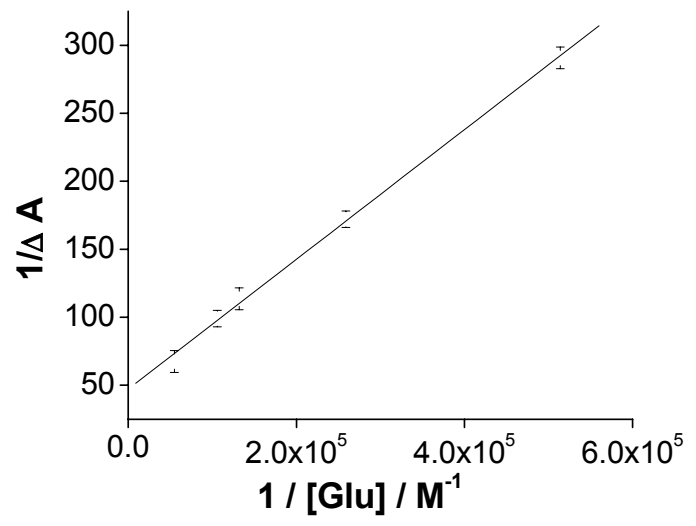

Fig S1a. Plot of 1 / $\Delta A$ at $478 \mathrm{~nm}$ Vs 1 / [Glu]

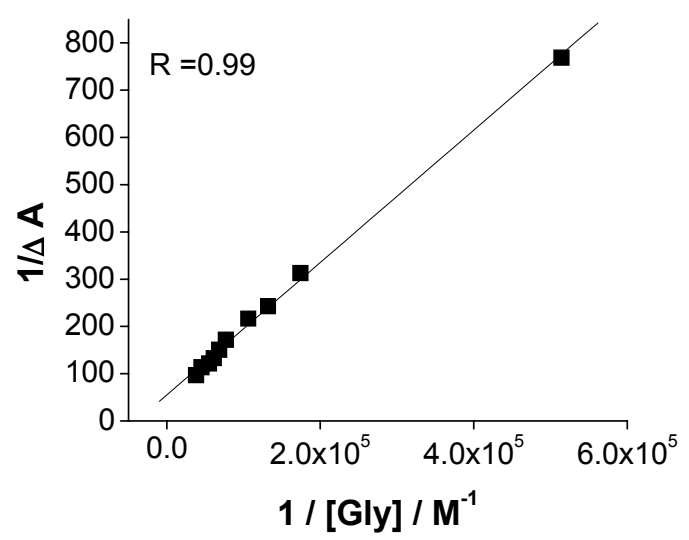

Fig S1b. Plot of 1 / $\Delta A$ at $478 \mathrm{~nm}$ Vs 1 / [Gly]

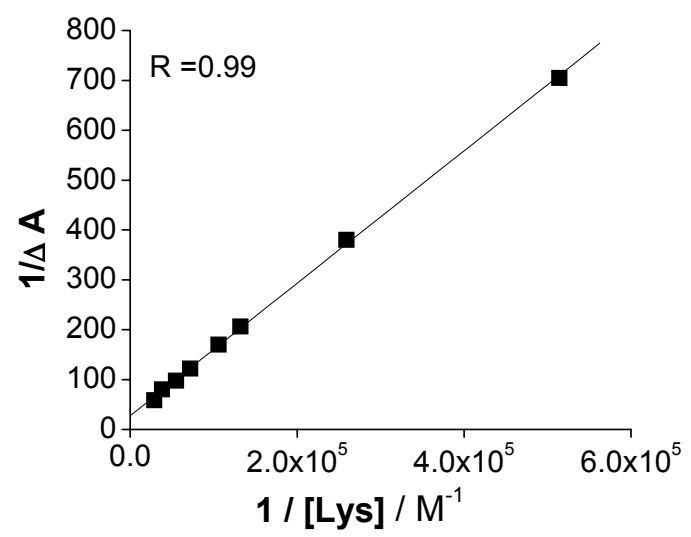

Fig S1c. Plot of 1 / $\Delta A$ at $478 \mathrm{~nm}$ Vs 1 / [Lys]

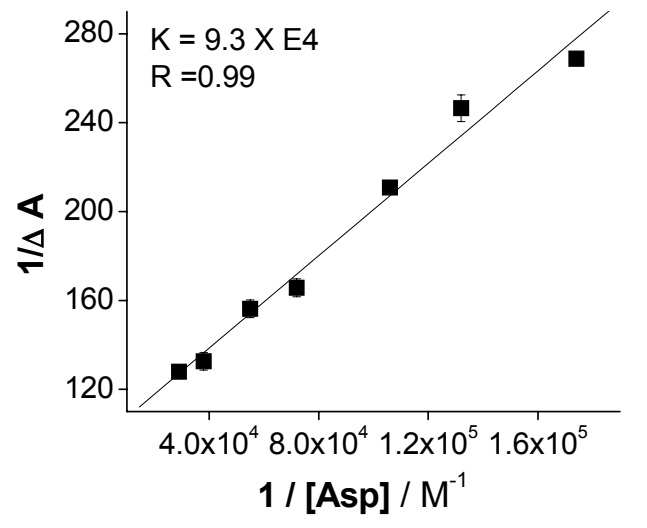

Fig S1d. Plot of 1 / $\Delta A$ at $478 \mathrm{~nm}$ Vs 1 / [Asp]

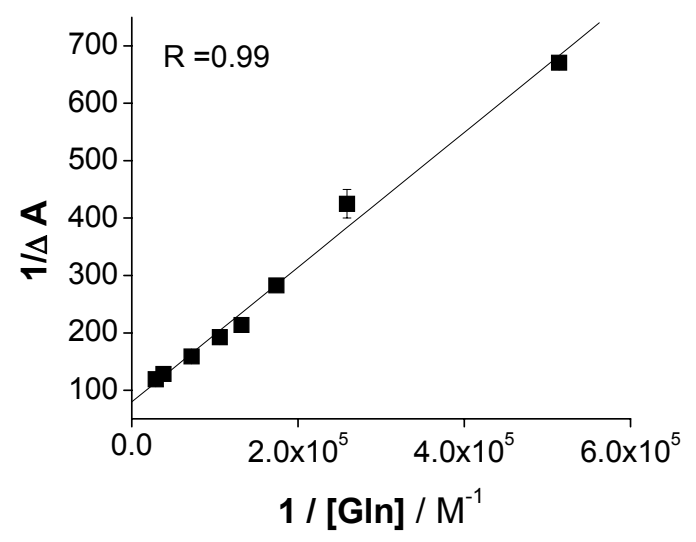

Fig S1e. Plot of 1 / $\Delta A$ at $478 \mathrm{~nm} \mathrm{Vs} 1$ / [GIn]

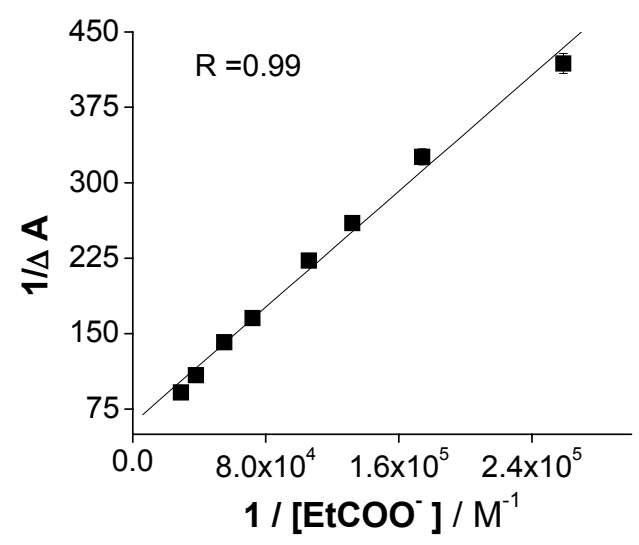

Fig S1f. Plot of $1 / \Delta A$ at $478 \mathrm{~nm} \mathrm{Vs} 1 /$ EtCO $\left._{2}^{-}\right]$ 


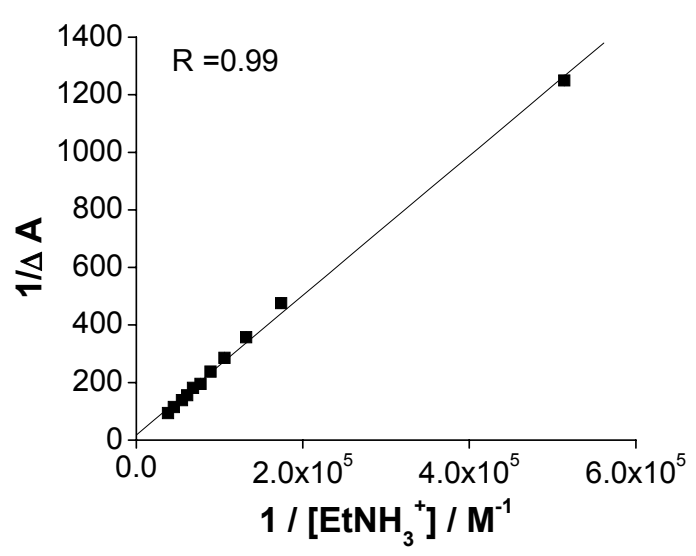

Fig S1g. Plot of $1 / \Delta A$ at $478 \mathrm{~nm} \mathrm{Vs} 1 /\left[\mathrm{EtNH}_{3}{ }^{+}\right]$

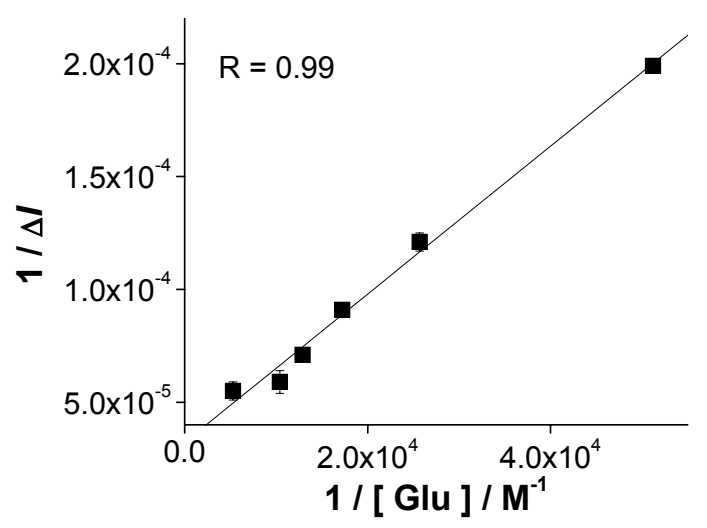

Fig S1h. Plot of 1/ $\Delta I$ at $554 \mathrm{~nm} \mathrm{Vs} \mathrm{1/[Glu]}$

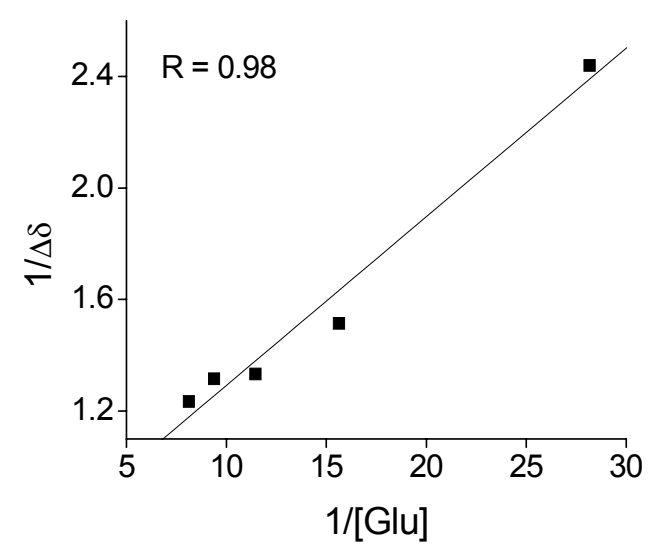

Fig S1i. Plot of $1 / \Delta \delta_{\mathrm{C}-3}$ Vs $1 /[$ Glu]

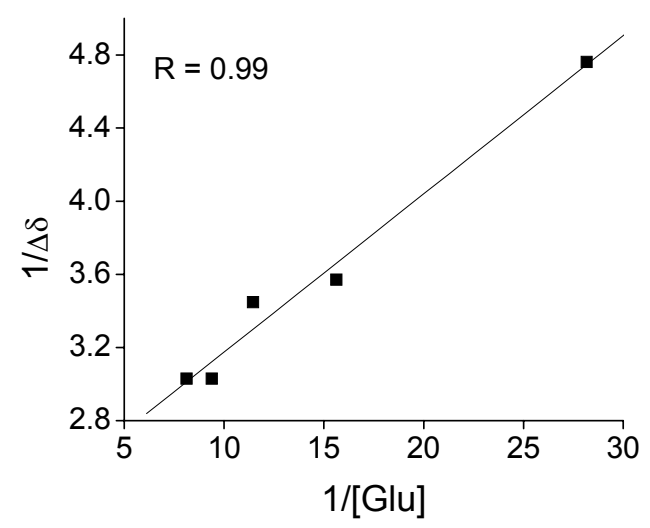

Fig S1j. Plot of $1 / \Delta \delta_{\mathrm{C}-7}$ Vs $1 /[$ Glu] 
${ }^{13}$ C-NMR spectra of 1 (Figure S2a).

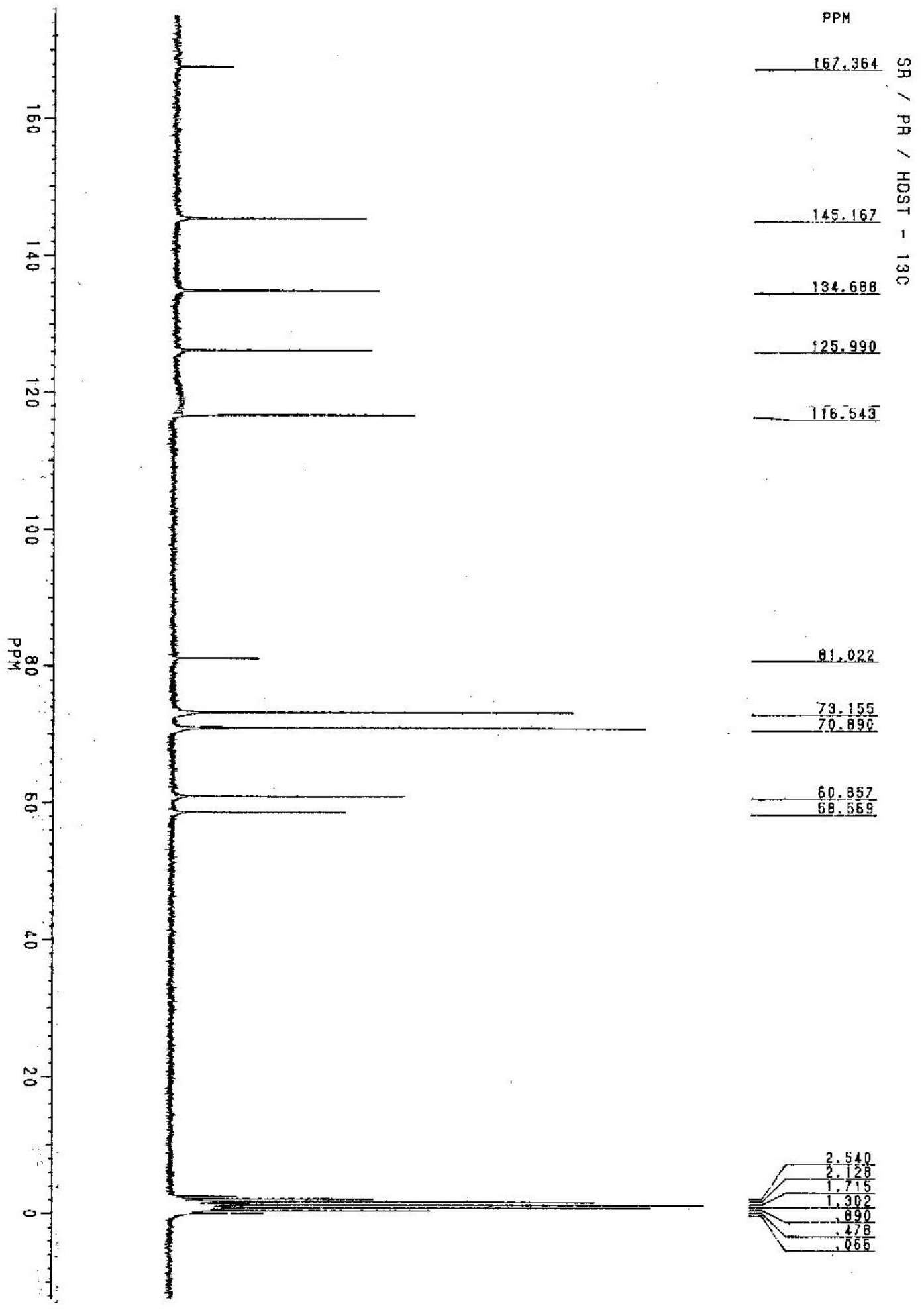


${ }^{13}$ C-NMR spectra of 1 after adding 1.25 molar equivalent of Glu (Figure S2b).
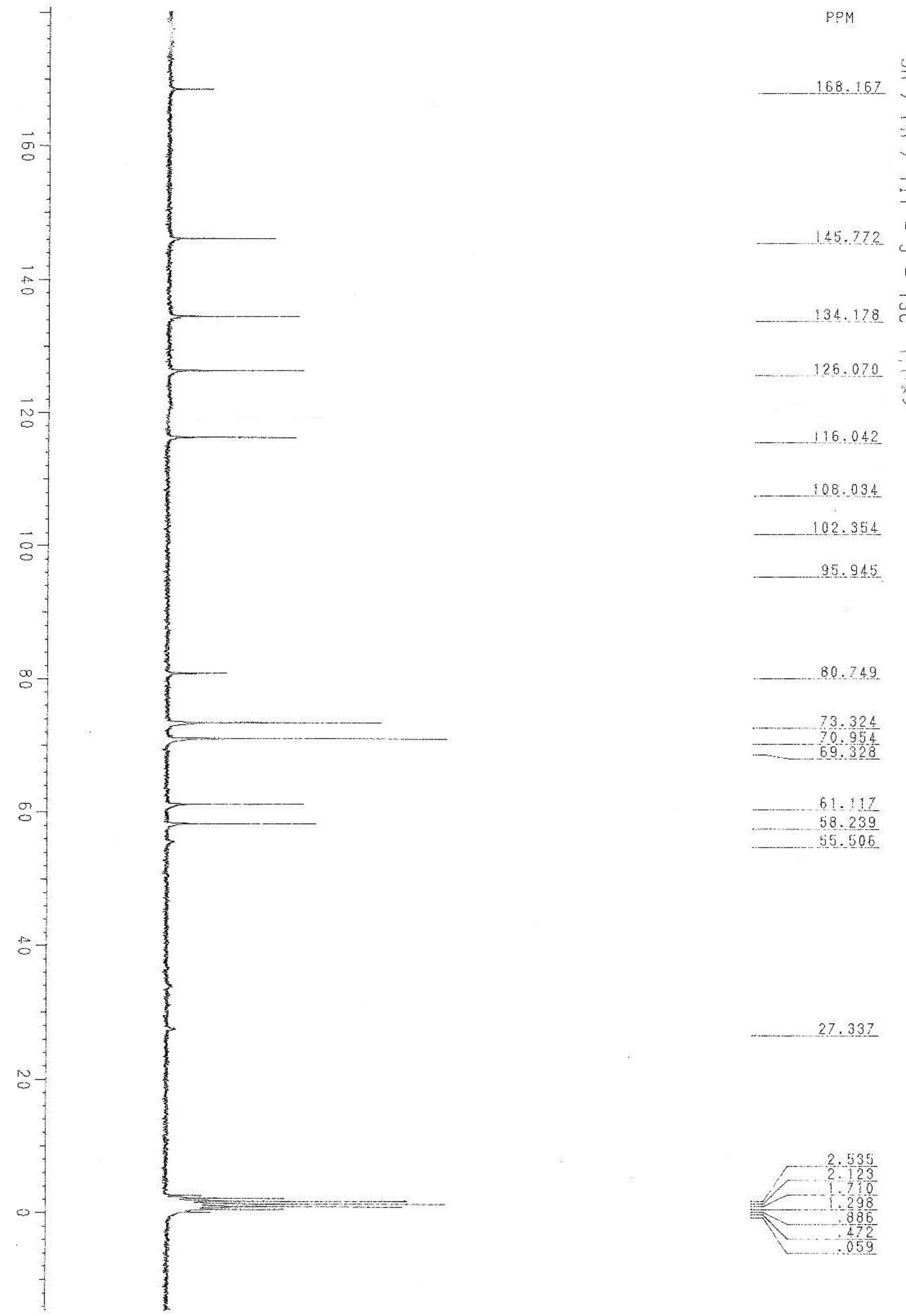

27.337

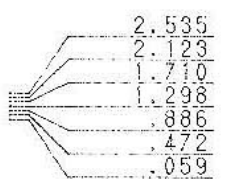


ESI-MS Spectra for the Binding of Receptor 1 and 2 with Various Guests.

\section{Receptor 1 in ES+ (Figure S3a)}

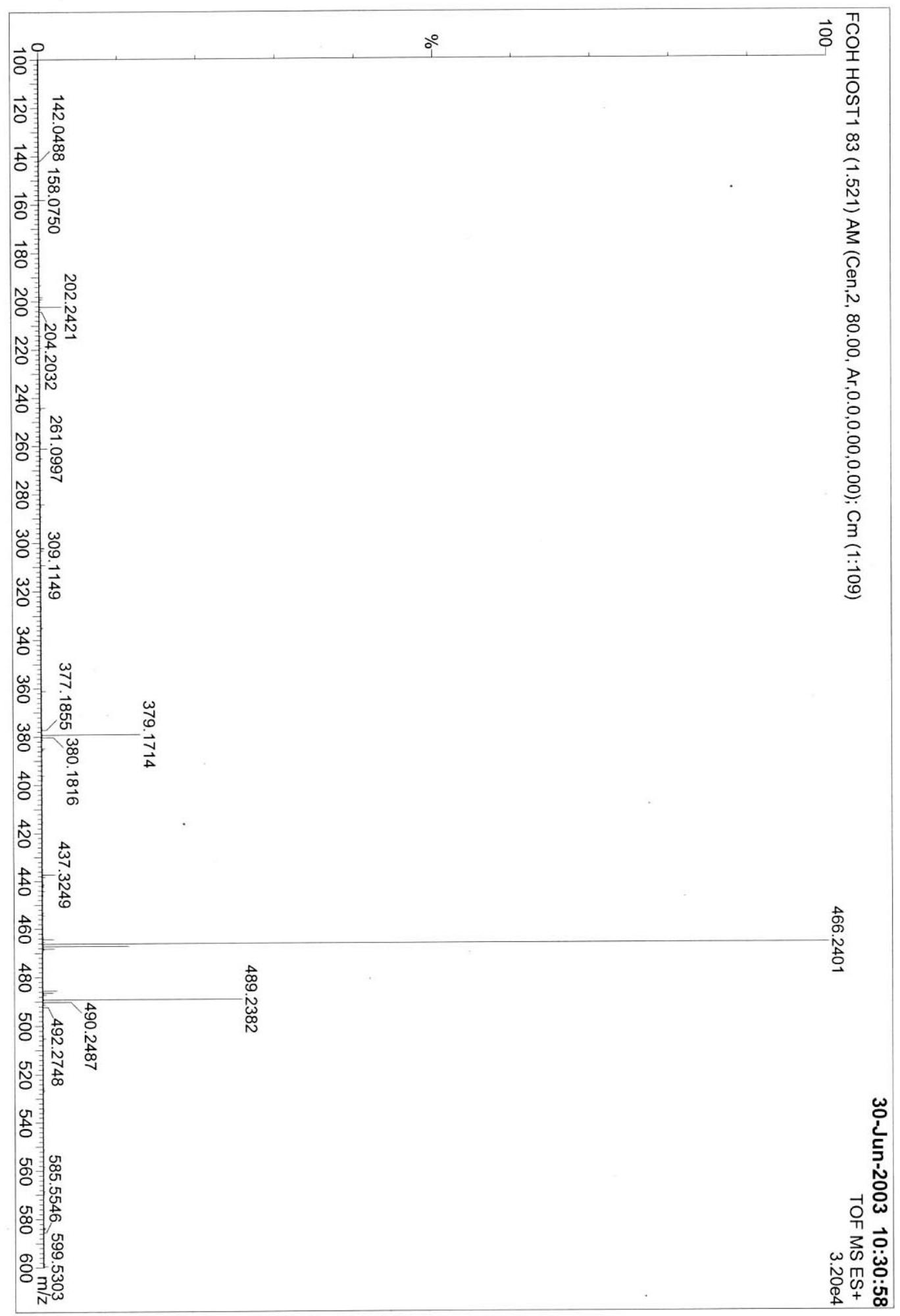


Receptor 1 in ES- (Figure S3b)

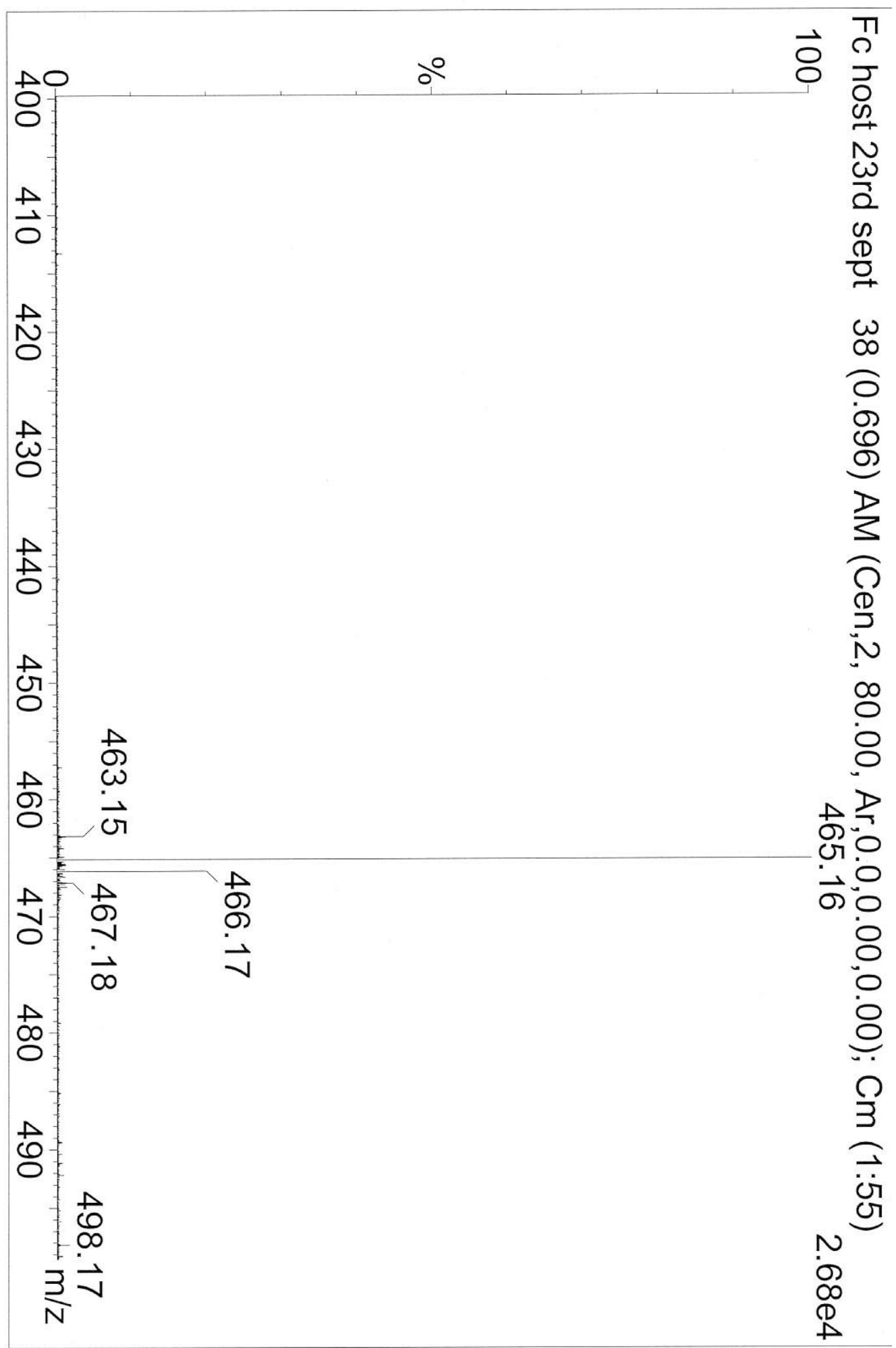


Glu in ES- (Figure S3c).

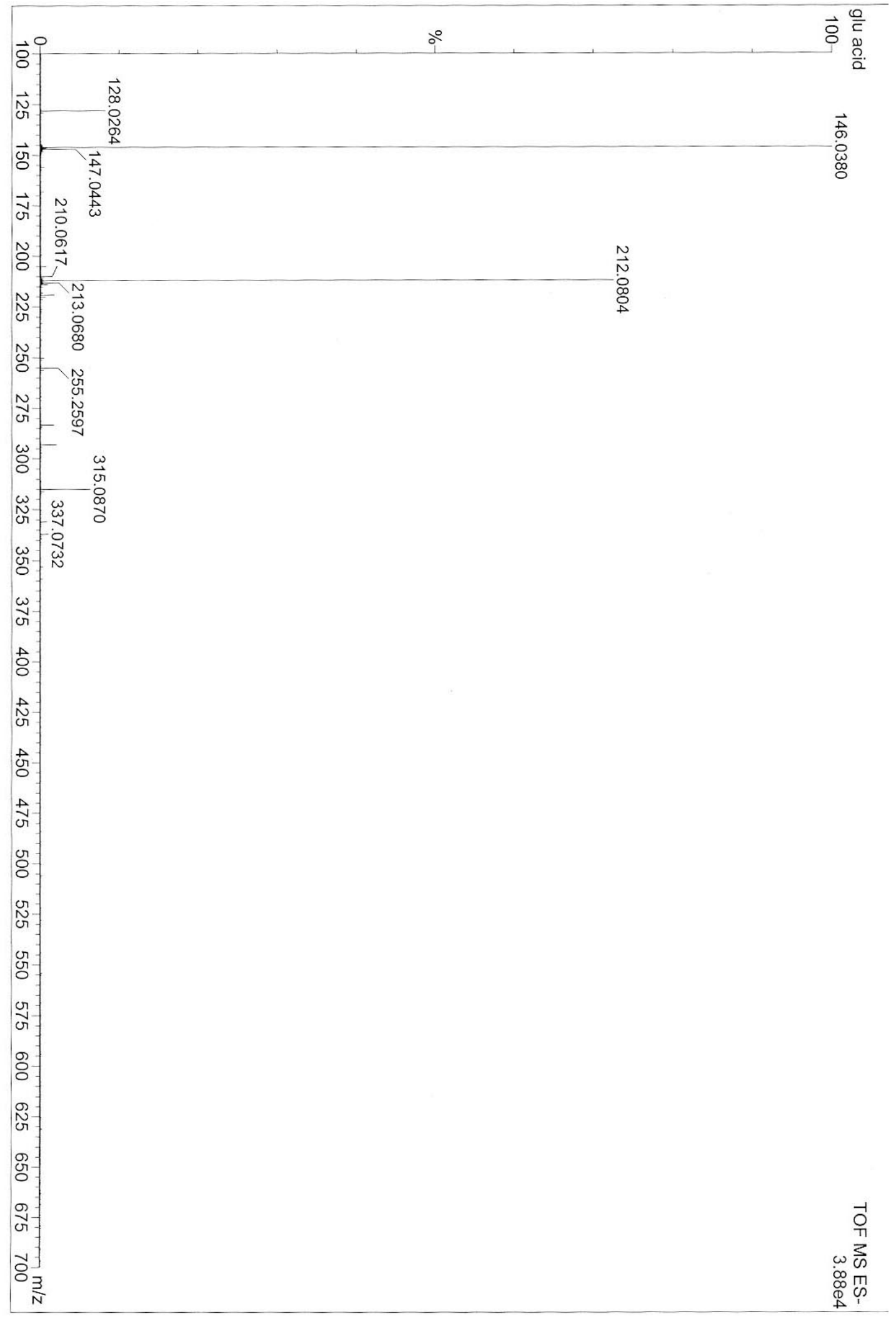


1 + Glu in ES- (Figure S3d).

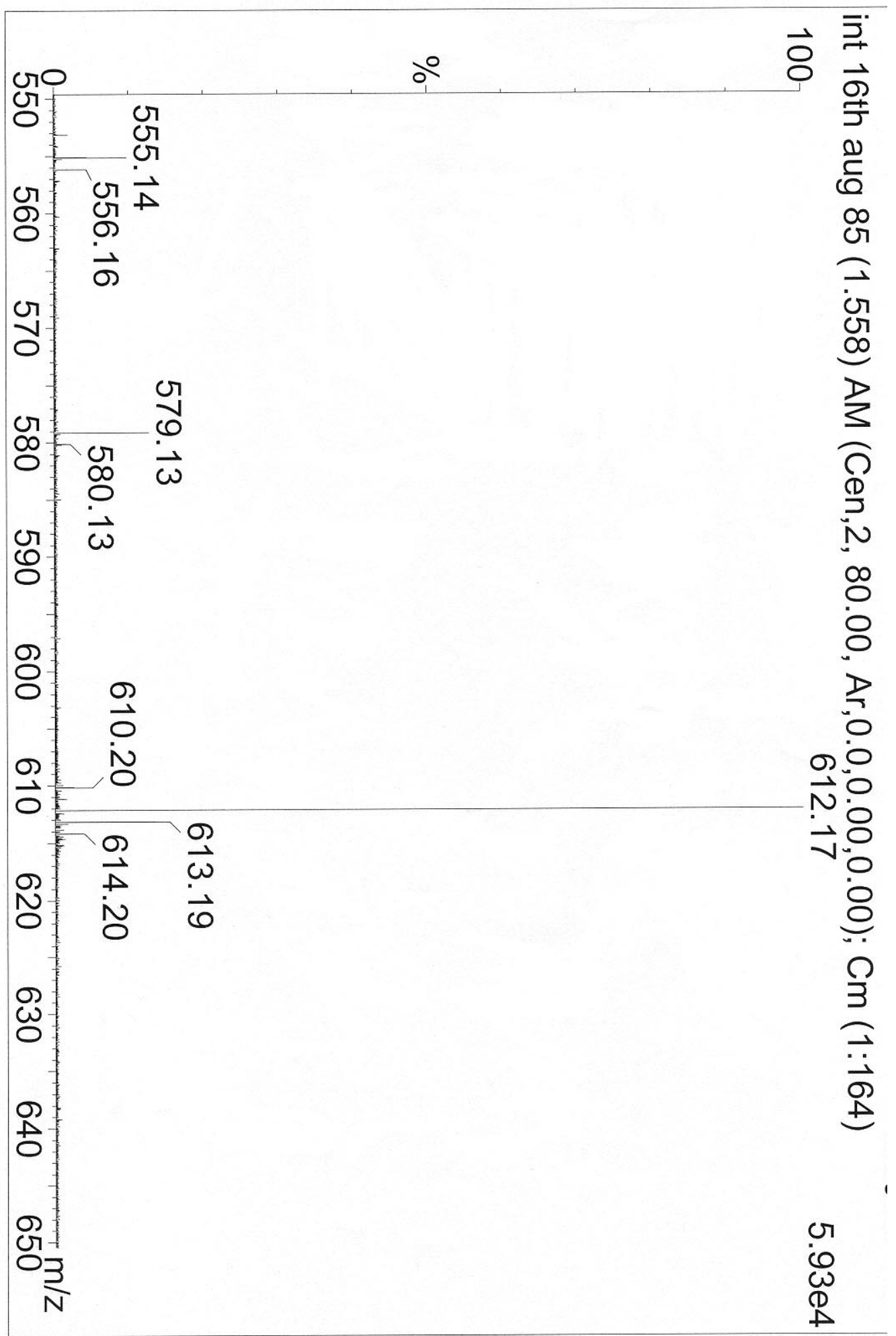


1 + Glu in ES+ (Figure S3e).

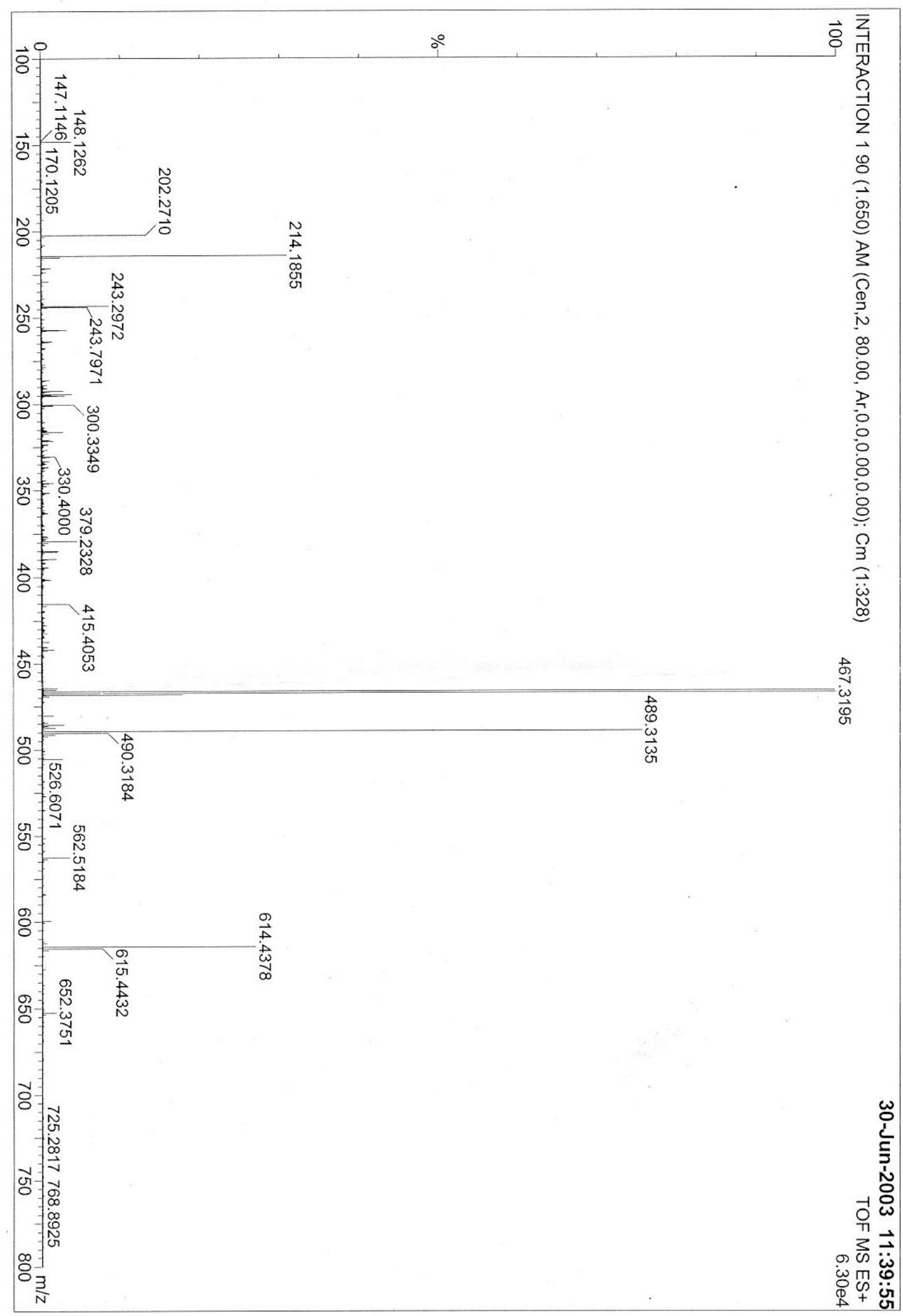


1 + Gly in ES+ (Figure S3f).

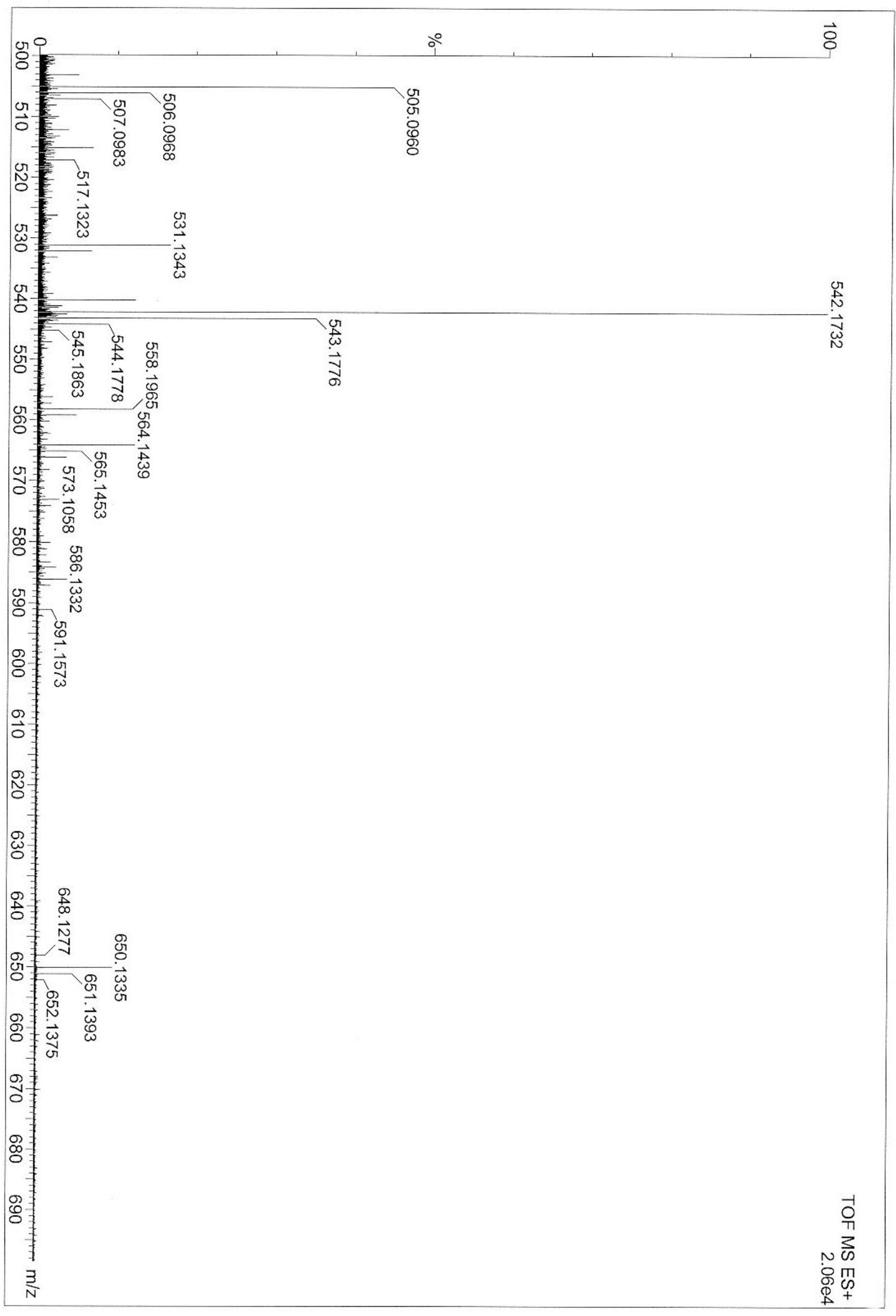


$1+$ Gly in ES- (Figure S3g).

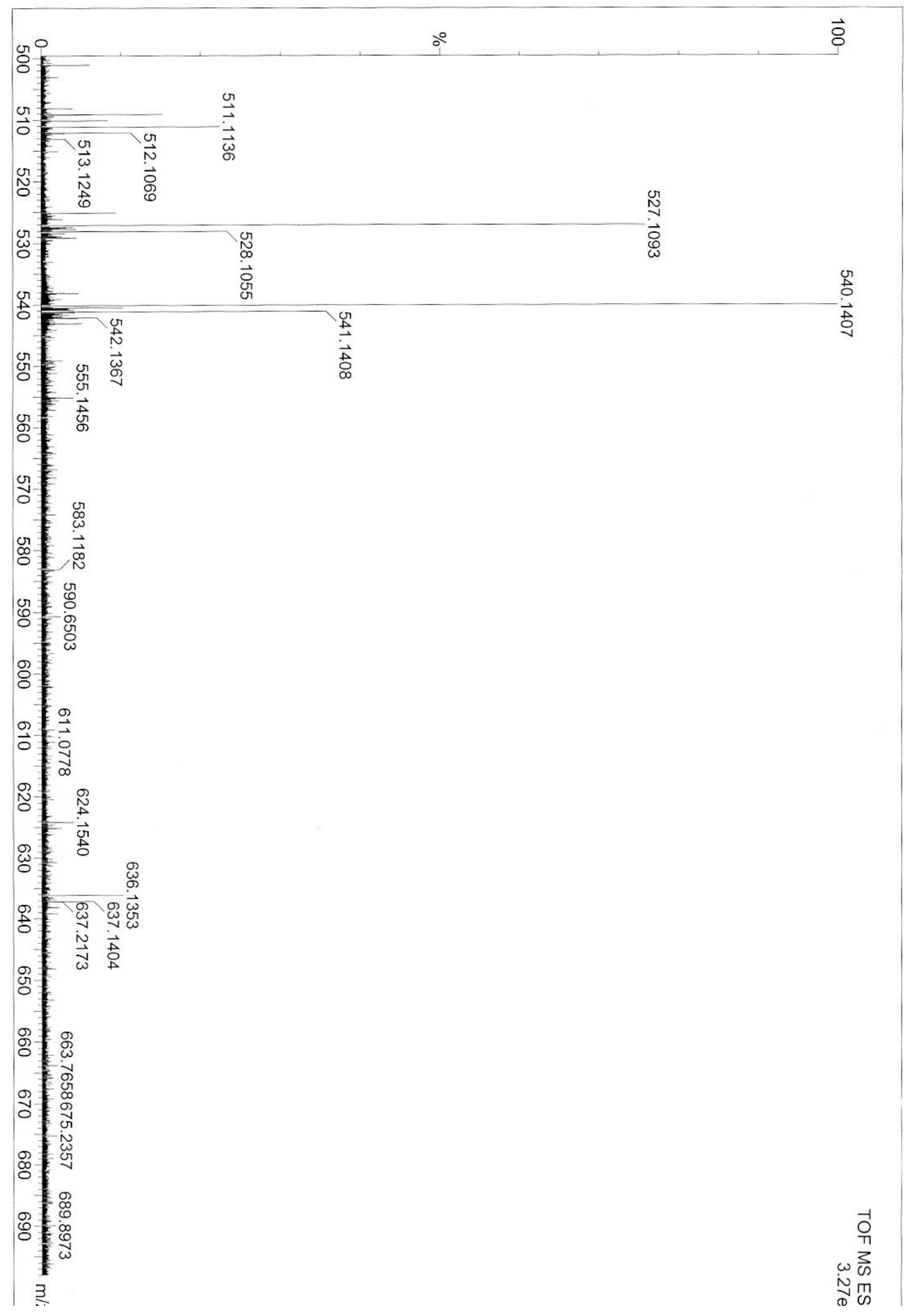


$1+$ EtCOO $^{-}$in ES- (Figure S3h).

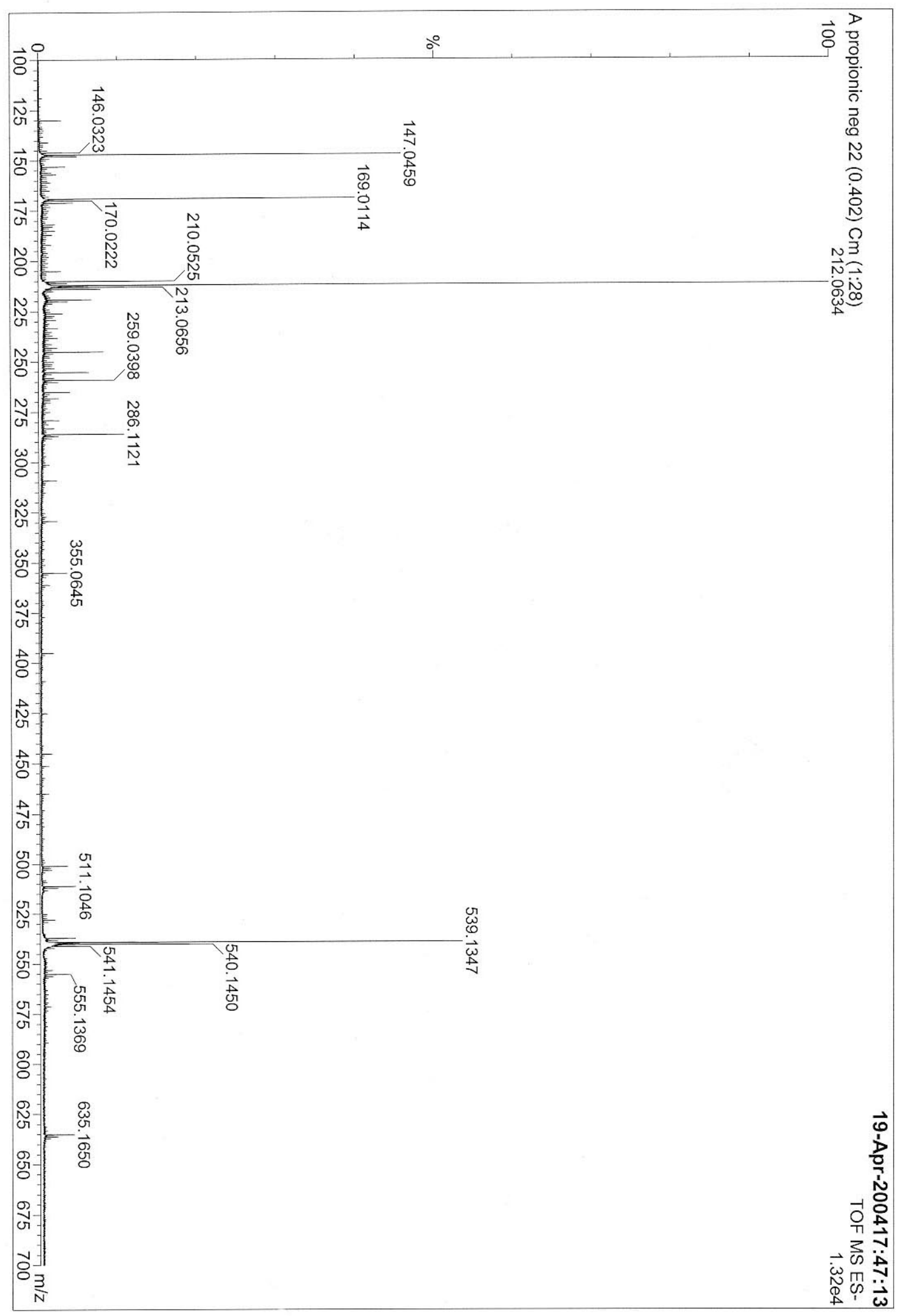


$1+\mathrm{EtNH}_{3}{ }^{+}$in ES$+($Figure S3i $)$.

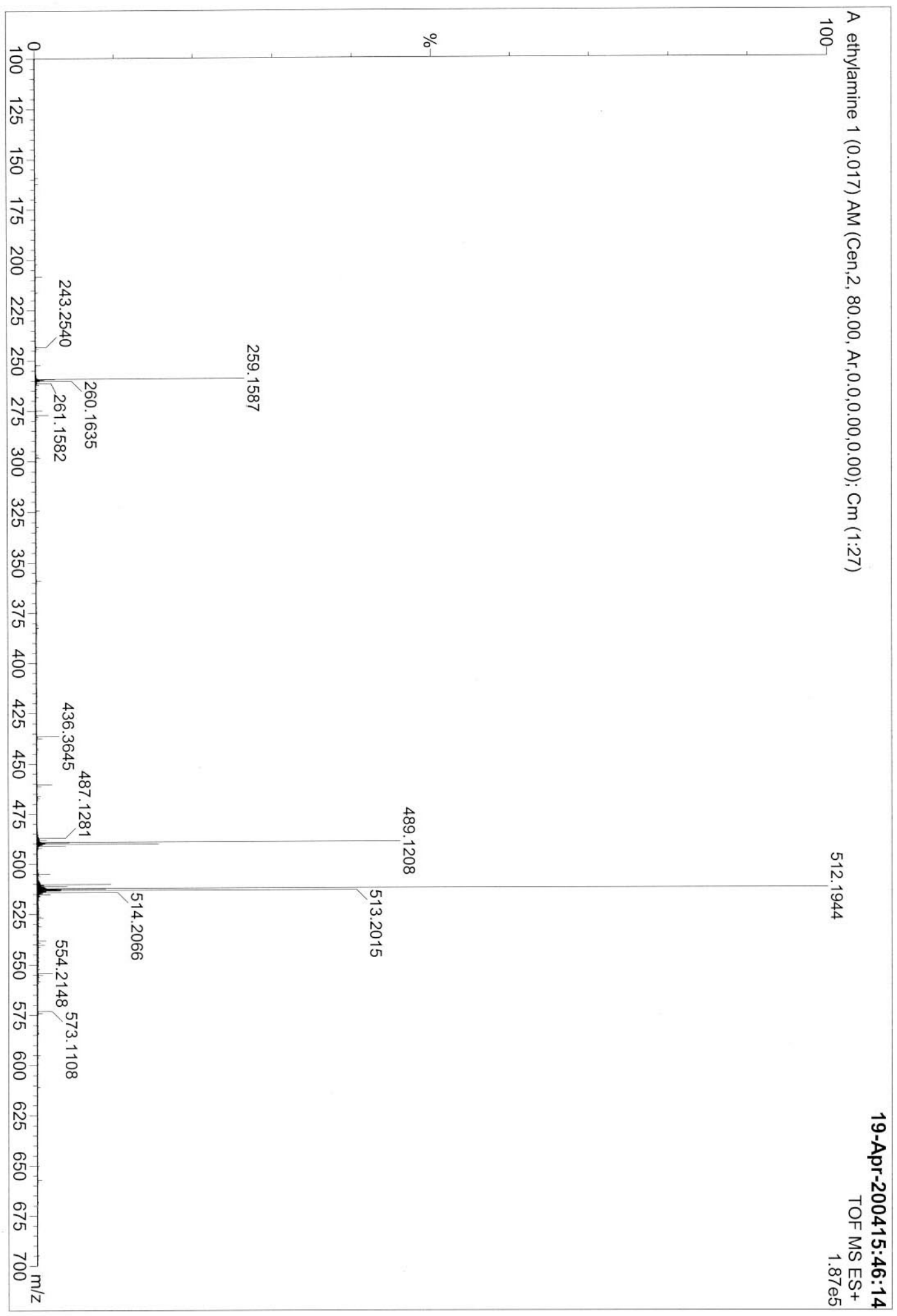


2 + Glu in ES+ (Figure S3j).

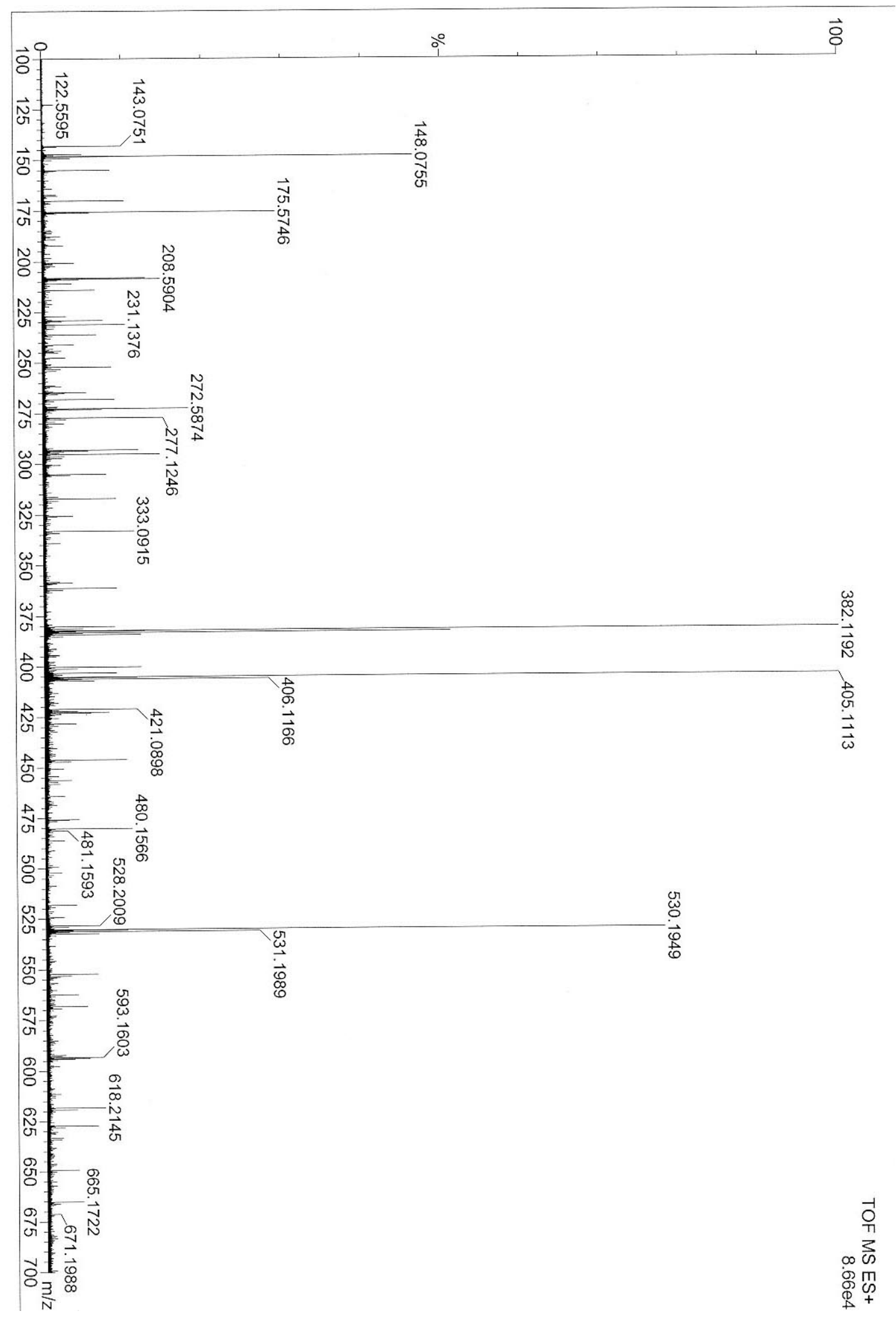




\section{$2+$ Gly in ES+ (Figure S3k).}

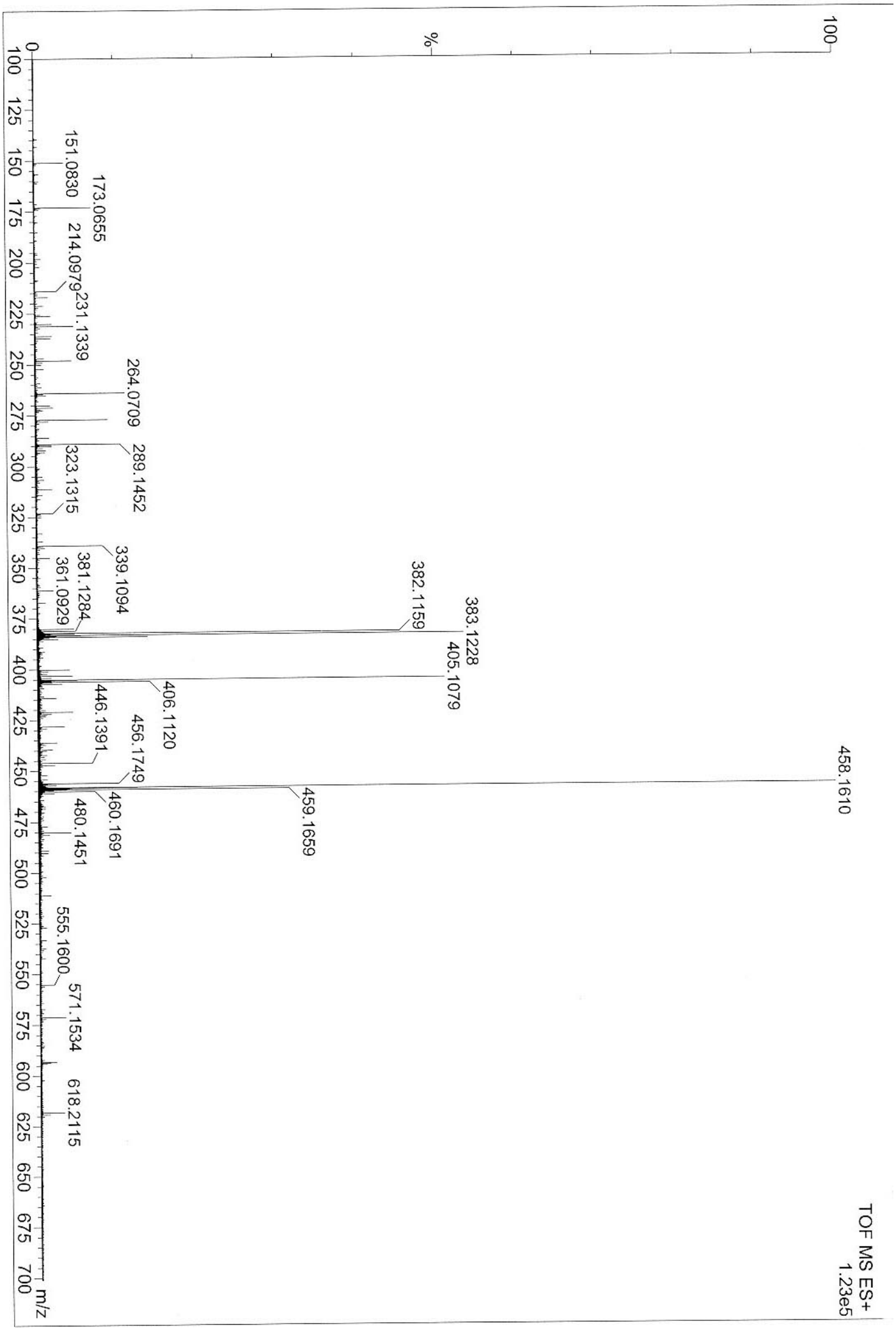




\section{$2+\mathrm{EtNH}_{3}{ }^{+}$in ES$+($Figure S3I).}

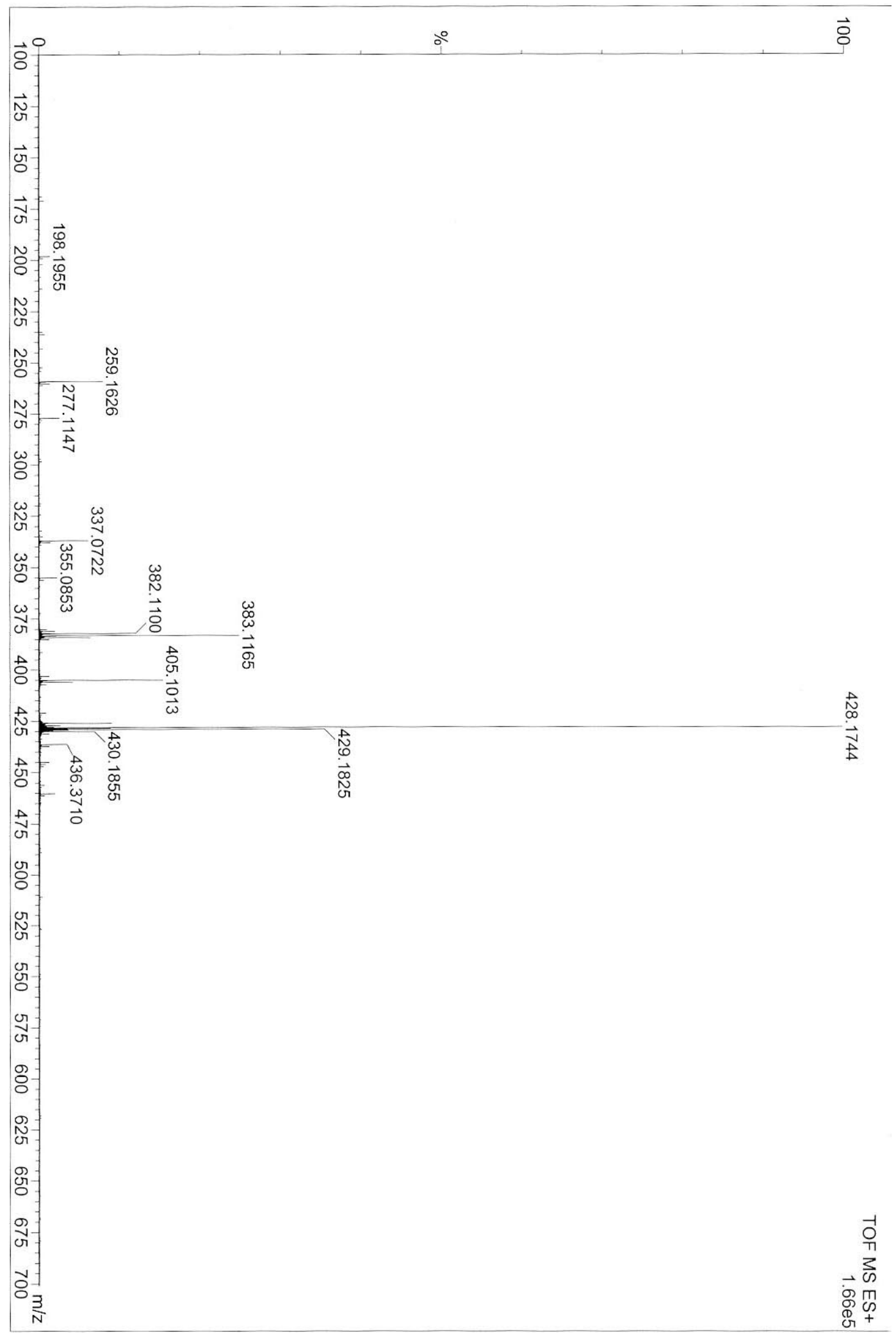




\section{Figure S4a-4f. CV of Receptor 1 after adding excess of Guest}

S4a. 1-Gln

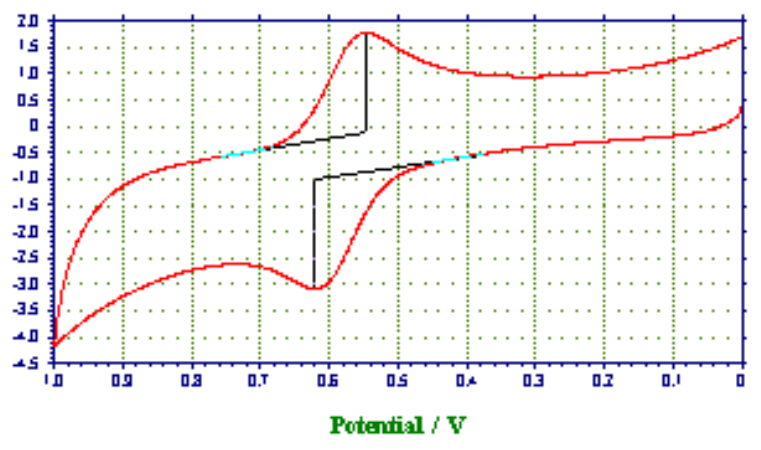

S4b. 1-Asp

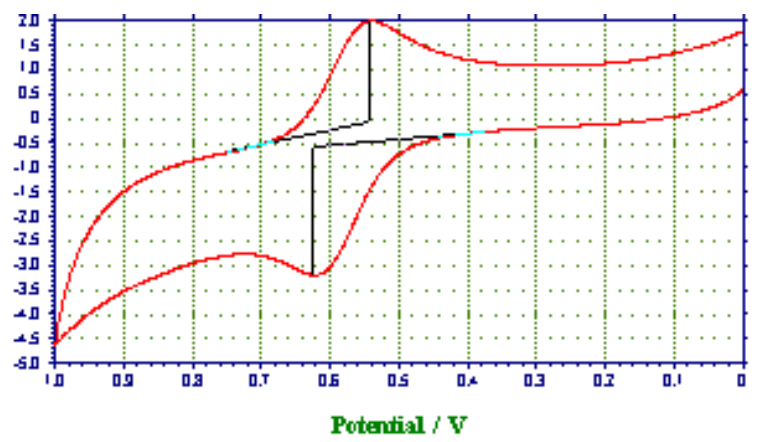

S4c. 1-Gly

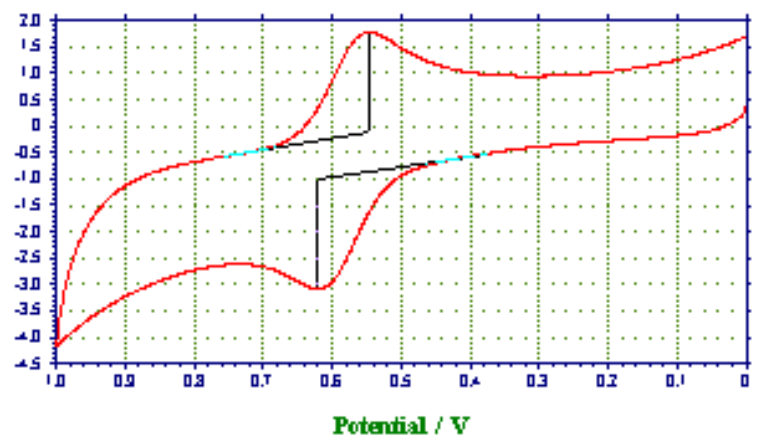

S4d. 1-Lys

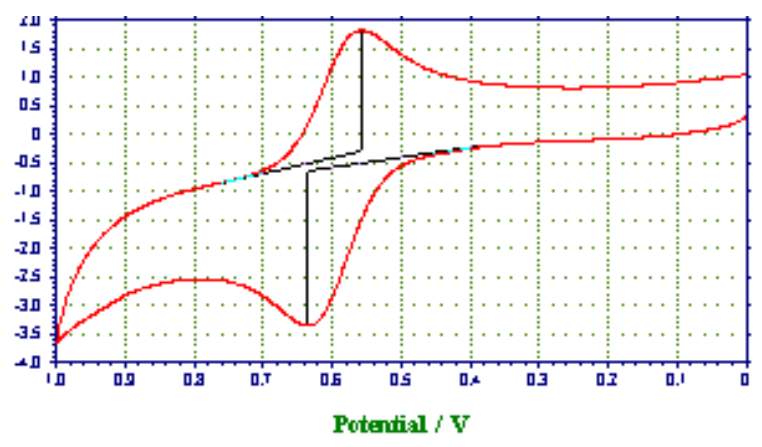

S4e. 1-Glu

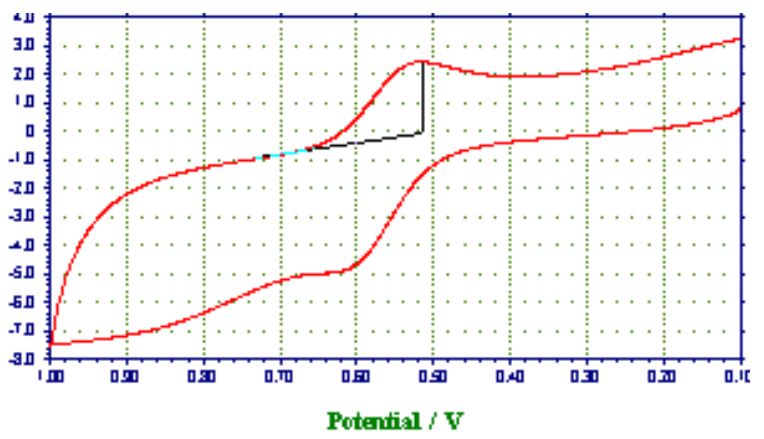

S4f. 1-Propionoic acid

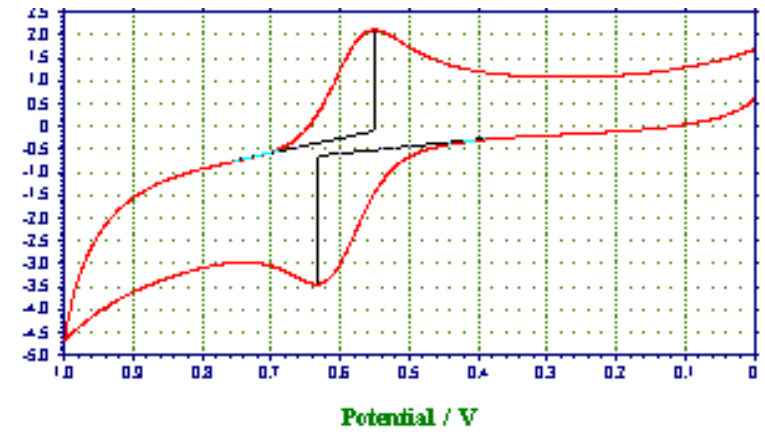


Table S1. Electrochemical data of receptor 1 before and after adding amino acid guests*

\begin{tabular}{lccccccc}
\hline Guest & $\begin{array}{c}E_{1 / 2} \\
(\mathrm{mV})\end{array}$ & $\begin{array}{c}\Delta E_{1 / 2} \\
(\mathrm{mV})\end{array}$ & $\begin{array}{c}E \mathrm{p}_{\mathrm{a}}-E \mathrm{p}_{\mathrm{c}} \\
(\mathrm{mV})\end{array}$ & $\begin{array}{c}\mathrm{Ip}_{\mathrm{a}} \\
\mu \mathrm{A}\end{array}$ & $\begin{array}{c}\mathrm{Ip}_{\mathrm{c}} \\
\mathrm{Ip}_{\mathrm{a}} / \mathrm{Ip}_{\mathrm{c}}\end{array}$ & $K_{\mathrm{ox}} / K_{\mathrm{red}}$ \\
\hline NIL & 664 & 0 & 80 & 6.4 & 5.9 & 1.1 & - \\
Glu & 566 & 98 & 103 & 4.0 & 2.7 & 1.5 & 45.9 \\
Asp & 582 & 82 & 82 & 2.6 & 2.1 & 1.2 & 24.5 \\
Gln & 584 & 80 & 73 & 2.1 & 1.9 & 1.1 & 22.7 \\
Gly & 584 & 80 & 74 & 2.1 & 2.0 & 1.1 & 22.6 \\
Lys & 595 & 69 & 80 & 2.7 & 2.2 & 1.2 & 14.8 \\
EtCO $_{2}^{-}$ & 592 & 72 & 84 & 2.8 & 2.2 & 1.3 & 16.5 \\
\hline
\end{tabular}

$* E_{1 / 2}$ defined as $\left(E \mathrm{p}_{\mathrm{a}}+E \mathrm{p}_{\mathrm{c}}\right) / 2$, and were reproducible up to $\pm 5 \mathrm{mV} . E_{1 / 2}{ }^{\text {complex }}$ obtained after adding 6 equiv. of guests. $\Delta E_{1 / 2}=\left(E_{1 / 2}{ }^{\text {free }}-E_{1 / 2}{ }^{\text {complex }}\right)$. Solvent is $\mathrm{MeCN}-\mathrm{H}_{2} \mathrm{O}$. Supporting electrolyte is ${ }^{\mathrm{n}} \mathrm{Bu}_{4} \mathrm{ClO}_{4}(0.1 \mathrm{M})$.

Figure S5. Plot showing linear correlation of $K_{0 x} / K_{\text {red }}$ ratio with $\Delta E_{1 / 2}$ value

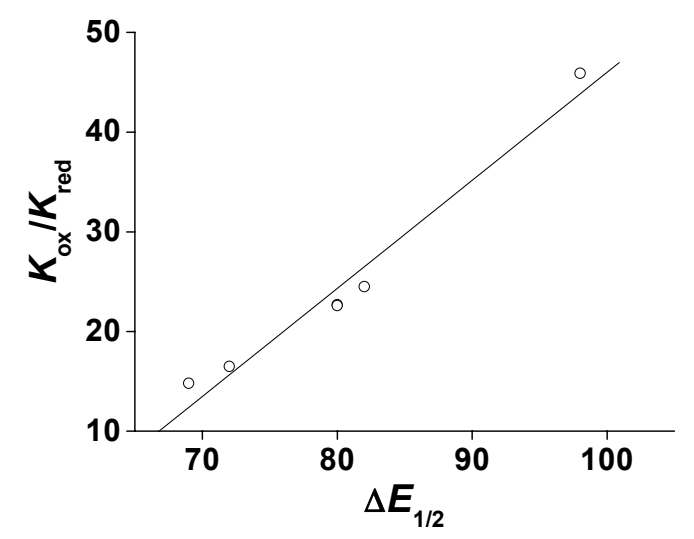

END OF SUPPORTING INFORMATION 